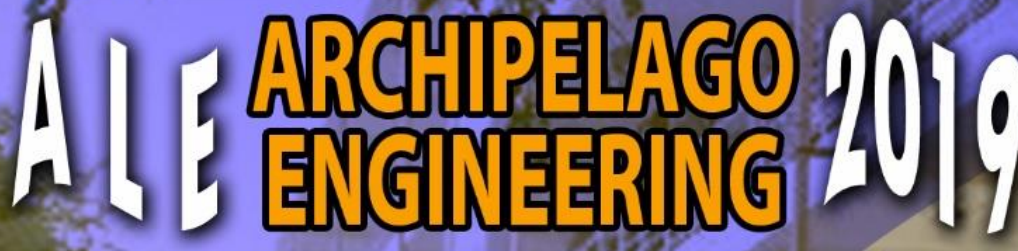

Fakultas Teknik Universitas Pattimura

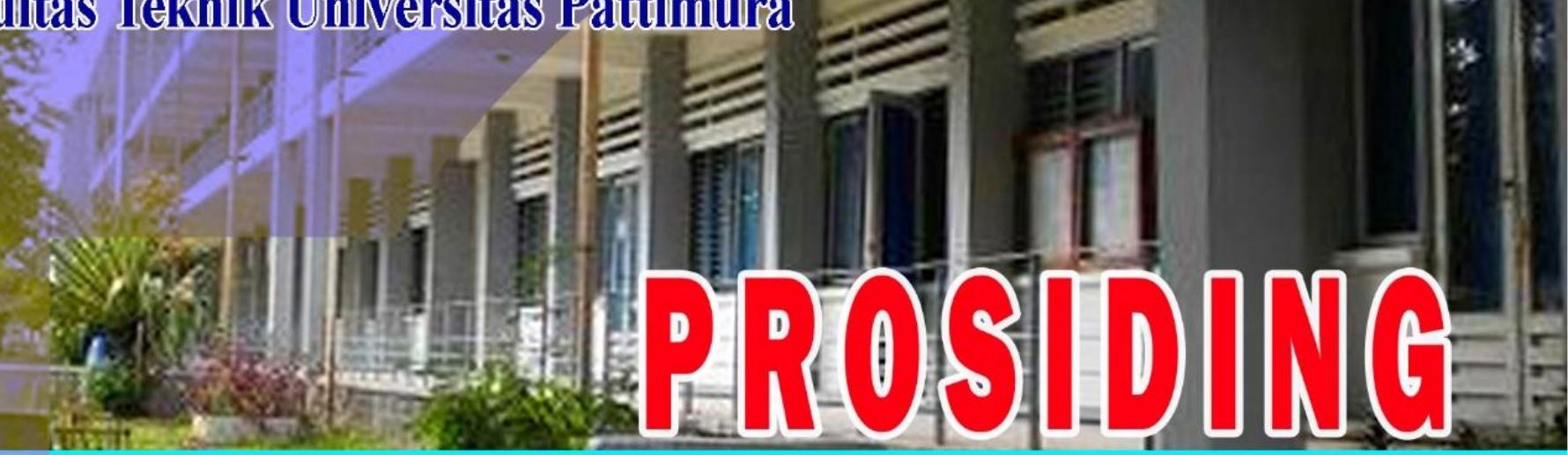

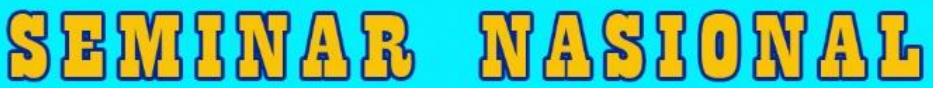

\section{ISSN: 2620-3995}

FAKULTAS TEKN IK UNIVERSITAS PATTIMURA KAMPUS POKA AMBON 10 APRIL 2019

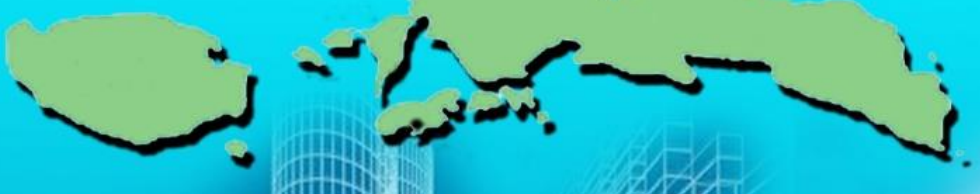

Hons

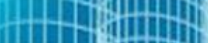

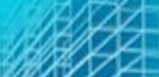

$102=0$
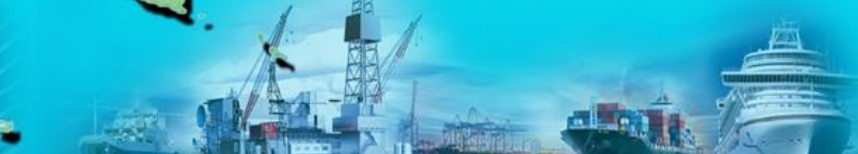

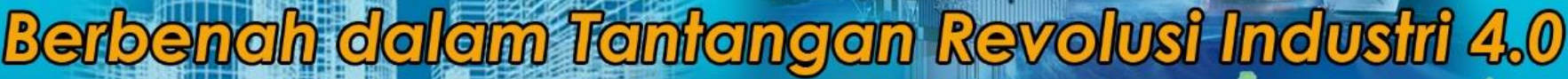

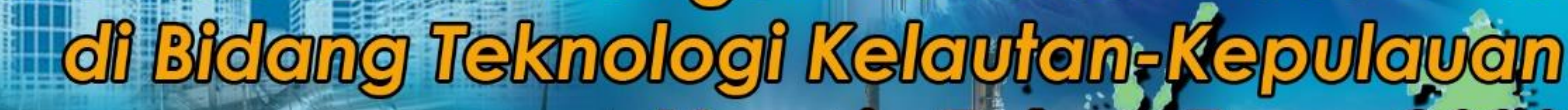

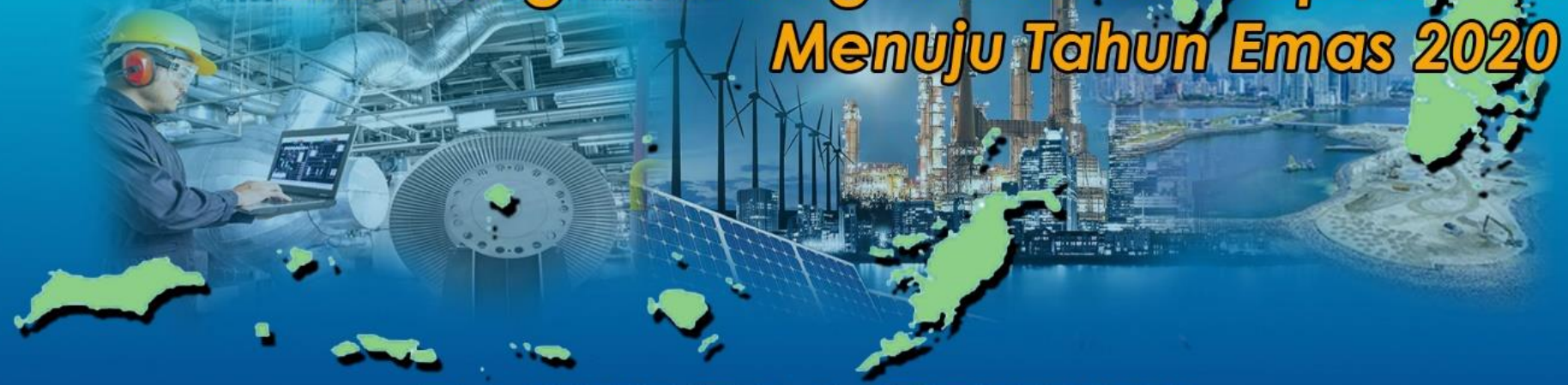

FARUITAS TREIRINIR

UINIVIRISITRAS PATTLIIIIURRA

ANBBON

2(1)129 

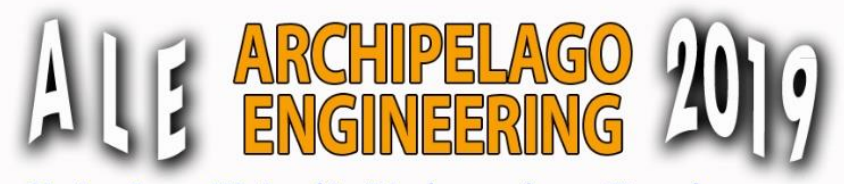

ISSN: 2620-3995

Fakultas Teknik Universitas Pattimura
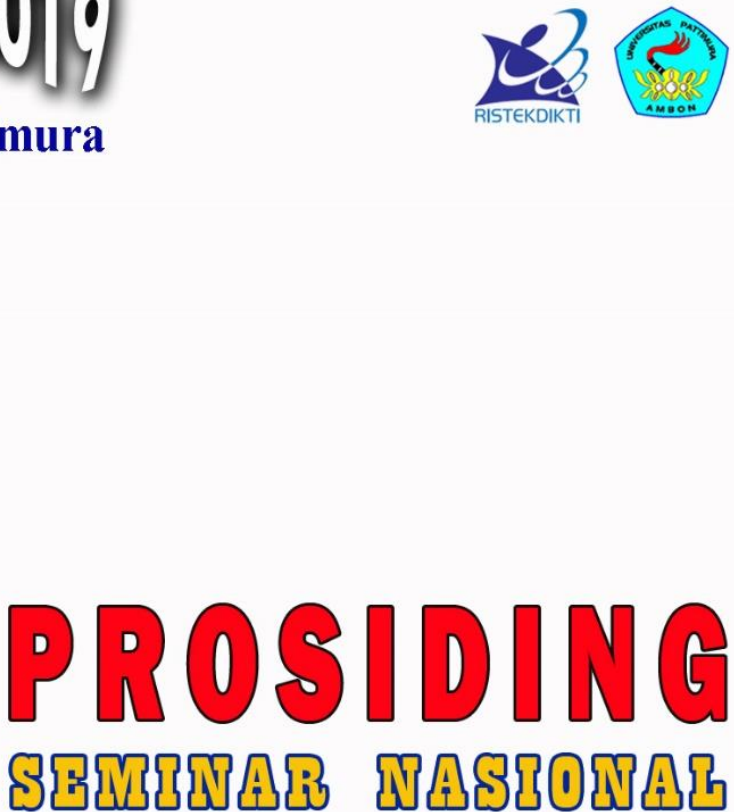

FAKULTASTEKNIK UNIVERSITAS PATTIMURA

KAMPUS POKA AMBON 10 APRIL 2019

Berbenah dalam Tantangan Revolusi Industri 4.0 di Bidang Teknologi Kelautan-Kepulauan Menuju Tahun Emas 2020

FAKULTAS TEKNIK

UNIVERSITAS PATTIMURA

AMBON

2019 


\section{SAMBUTAN DEKAN FAKULTAS TEKNIK UNPATTI}

Assalamulaikum Warohmatullahi Wabarakatuh,

Salam Sejahtera.

Marilah kita panjatkan puji syukur kepada Tuhan Yang Maha Kuasa yang telah memberikan rahmat dan karuniaNya sehingga kegiatan Seminar Nasional ke -2 Archipelago Engineering 2019 dengan tema "BERBENAH DALAM TANTANGAN REVOLUSI INDUSTRI 4.0 DI BIDANG TEKNOLOGI KELAUTAN KEPULAUAN MENUJU TAHUN EMAS 2020" dapat terselenggara dengan baik dan lancar.

Atas nama Keluarga Besar Fakultas Teknik Unpatti, perkenankan saya menyampaikan Selamat Datang di Kampus Fakultas Teknik kepada Bapak Prof. Adi Suryosatyo dari Universitas Indonesia, Bapak Dr. I Made Ariana, ST., MT. dari ITS dan dan Ibu Cathy Garden dari Selandia Baru sebagai Keynote Speakers, para pemakalah dan peserta dari luar Universitas Pattimura guna mengikuti seminar ini.

Saya menyambut gembira karena kegiatan Seminar ALE 2019 ini mendapatkan perhatian yang besar dari para dosen di lingkup Fakultas Teknik Unpatti sehingga lebih dari 40 makalah akan dipresentasikan dalam seminar ini. Untuk itu, saya menyampaikan terima kasih dan penghargaan yang setinggi-tingginya kepada Bapak dan Ibu para pemakalah. Saya yakin bahwa dari seminar ini akan menghasilkan ide-ide, konsepkonsep, teknik-teknik dan terobosan-terobosan baru yang inovatif dan bersinergi dengan pengembangan pola Ilmiah Pokok Unpatti terutama di bidang Kelautan Kepulauan.

Seminar ini terselenggara dengan baik karena dukungan dari berbagai pihak, khususnya para sponsor dan kontribusi dari pemakalah dan peserta. Untuk itu, saya menyampaikan terima kasih yang sebesarbesarnya.

Secara khusus, saya menyampaikan terima kasih dan penghargaan yang setinggi-tingginya kepada Panitia Penyelenggara atas jerih payah, kerja keras, ketekunan dan kesabarannya dalam mempersiapkan dan menyelenggarakan seminar ini sehingga dapat berjalan baik, lancar dan sukses.

Akhirnya, melalui seminar ini, marilah kita senantiasa perkuat dan perluas jejaring serta kerjasama antar sesama dosen sebagai pendidik, peneliti dan pengabdi kepada masyarakat dalam mewujudkan Tri Dharma Perguruan Tinggi guna membangun bangsa dan negara tercinta.

Ambon, 10 April 2019

Dekan Fakultas Teknik Unpatti,

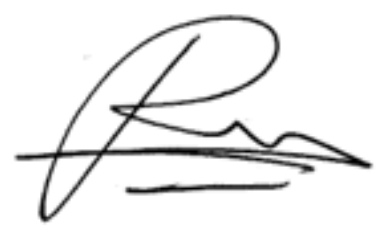

Dr. Ir. W. R. Hetharia, M.App.Sc 


\section{SUSUNAN PANITIA PELAKSANA 2019}

Dr. Novitha L. Th. Thenu, ST., MT

Nikolaus Titahelu, ST, MT

Dr. Debby R. Lekatompessy, ST., MT

Ir. W. M. E. Wattimena, MSc

Danny Pailin Bunga, ST, MT

Ir. Latuhorte Wattimury, MT

N. Maruanaya, SH

Ir. H. C. Ririmasse, MT

Ir. John Latuny, MT, PhD

SEKSI SEMINAR ALE 2019

W. M. Rumaherang, ST., MSc, PhD

D. S. Pelupessy, ST, MSc, PhD

Prayitno Ciptoadi, ST, MT Benjamin G. Tentua, ST, MT

Mercy Pattiapon, ST, MT Meidy Kempa, ST, MT 
HALAMAN JUDUL

Teknik Perkapalan, Teknik Transportasi Laut

E. R. de FRETES :

Analisa Parametrik Channel Flow pada Lambung Kapal Cepat untuk Memperoleh Wake Maksimum. Studi Kasus: Kapal Cepat Rute Ambon Wayame

SONJA TREISJE A. LEKATOMPESSY:

Pengaruh Variasi Parameter Pengelasan Terhadap Kualitas Hasil Pengelasan

OBED METEKOHY :

Analisa Pengaruh Karakteristik Teknis Desain Terhadap Proses Setting Kapal Pukat

Cincin di Maluku

HELLY S. LAINSAMPUTTY :

Analysis Of Principle Dimension And Shape Of Purse Seiners In Ambon Island

WOLTER R. HETHARIA, A. FENINLAMBIR, J. MATAKUPAN, F. GASPERSZ:

Pengaruh Dimensi Terhadap Parameter Stabilitas Kapal-Kapal Penumpang Kecil

Material FRP

LEKATOMPESSY DEBBY R, SOUMOKIL RUTH P, RIRIMASSE HEDY C. :

Analisa Response Dinamik Pada Sambungan Konstruksi Kapal Kayu Berdasarkan Tipe

Mesin Yang Digunakan

EDWIN MATATULA:

Studi Pemilihan Jenis Alat Angkut Bahan Bakar Minyak Wilayah Kepulauan

MONALISA MANUPUTTY :

Pengaruh Getaran Dan Kebisingan Terhadap Kelelahan Kerja Pada Awak Kapal Ikan

Tipe Pole And Line

\section{Teknik Sistem Perkapalan}

ABDUL HADI, B. G. TENTUA :

Algoritma Simulasi Numerik Getaran Dirrect Inline Harmonical Cam Follower Pada

Valve Train Manifold Motor Diesel

DANNY S. PELUPESSY :

Studi Karakteristik Momen Torsi Akumulator Pegas Untuk Penggerak Langkah (StepDrives)

JACOB D. C. SIHASALE, JERRY R. LEATEMIA :

Analisis Penampatan Lokasi Station AIS (Automatic Identification Sistem) Di Ambon

Guna Mendukung Monitoring ALKI (Alur Laut Kepulauan Indonesia) III Secara

Maksimal

LATUHORTE WATTIMURY :

Tinjauan Analisa Kerja Signal AF dan RF Terhadap Kinerja Peralatan Pemancar Dan

Penerima Stasiun Radio Pantai Distrik Navigasi Ambon

MESAK FRITS NOYA, ABDUL HADI :

Studi Eksperimental Pengaruh Posisi Pengelasan Terhadap Sifat Mekanis Baja Karbon

Rendah 
NOVITHA L. TH. THENU :

Pemisahan Sinyal Bunyi Dari Microphone Array Dengan Menggunakan Metode Blind

Source Separation - Independent Component Analysis Untuk Memantau Kondisi Poros

Retak

PRAYITNO CIPTOADI :

Pengaruh Variasi Diameter Pipa Isap Terhadap Karakteristik Pompa Sentrifugal

Teknik Mesin, Teknik Informatika, Teknik Elektro

ANTONI SIMANJUNTAK, JOHANIS LEKALETTE :

PLTS di Pulau Osi dan Permasalahannya

BENJAMIN GOLFIN TENTUA, ARTHUR YANNY LEIWAKABESSY :

Studi Eksperimental Sifat Mekanis Tarik dan Bending Komposit Serat Empulur Sagu

JANDRI LOUHENAPESY, SEFNAT J. ETWAN SARWUNA :

Analisa Kinerja Rem Cakera Akibat Modifikasi Kaliper Roda Belakang Terhadap

Keselamatan Pengendara Sepeda Motor

NICOLAS TITAHELU, CENDY S. E. TUPAMAHU:

Analisis Pengaruh Masukan Panas pada Oven Pengering Bunga Cengkeh Terhadap

Karakteristik Perpindahan Panas Konveksi Paksa

W. M. RUMAHERANG :

Evaluasi Karakteristik Energy Torque Converter Berdasarkan Pengaruh Rasio Putaran

Terhadap Koefesien Torsi dan Efesiensi

ELVERY B. JOHANNES :

Indexing pada Sistem Penalaran Berbasis Kasus Menggunakan Metode Complete-

Linkage Clustering

SAMY J. LITILOLY, NICOLAS TITAHELU :

Laser Semikonduktor GaAs Jenis Double Heterojunction Sebagai Sumber Cahaya dalam Komunikasi Optik

\section{Teknik Industri}

ALFREDO TUTUHATUNEWA :

Model Agile Supply Chain Industri Perikanan di Kota Ambon

AMINAH SOLEMAN :

Analisis Beban Kerja Mental Dan Fisik Karyawan Pada Lantai Produksi Dengan

Metode Nasa-Tlx Dan Cardiovascularload

DANIEL B. PAILLIN, JOHAN M TUPAN, RIZKI ANGGRAENI UTAMI PUTRI :

Penerapan Algoritma Differential Evolution untuk Penyelesaian Permasalahan

Capacitated Vehicle Routing Problem (CVRP). (Studi Kasus: PT. Paris Jaya Mandiri)

MARCY L. PATTIAPON, NIL EDWIN MAITIMU :

Perencanaan Produksi Kerajinan Kulit Kerang Mutiara dengan Menggunakan Metode

Agregat di Kota Ambon

J. M. TUPAN :

Desain Pemasaran Online Berbasis Web untuk Pemasaran Produk Kerajinan Kerang

Mutiara di Kota Ambon. (Studi Kasus: Pondok Mutiara)

NIL EDWIN MAITIMU, MARCY L. PATTIAPON :

Penerapan Economic Order Quantity (EOQ) Guna Menganalisa Pengendalian

Persediaan Bahan Baku Daging Buah Pala pada Usaha Kecil Menengah (UKM) Hunilai di Dusun Toisapu Desa Hutumuri

RICHARD A. de FRETES :

Pengembangan Komunitas Pesisir Di Kecamatan Leitimur Selatan dengan

Memanfaatkan Kearifan Lokal 
MOHAMMAD THEZAR AFIFUDIN, ARIVIANA LIENTJE KAKERISSA :

Aplikasi Pendekatan N-Stage untuk Masalah Pengrutean dan Penjadwalan TrukTunggal di Daerah Kepulauan. (Studi Kasus pada Koperasi Unit Bersama Negeri Booi, Saparua)

W. LATUNY :

Memprediksi Harga Jual Rumput Laut Kering Pada Tingkat Petani Dengan Data Mining

IMELDA CH. POCERATU :

Implementasi Ekoteologi dalam Pencegahan Pencemaran Lingkungan Laut di Pasar Arumbai Ambon

Teknik Sipil, Perencanaan Wilayah \& Kota

A. KALALIMBONG :

Tinjauan Hasil Peningkatan Saluran Suplesi Geren Meten Pulau Buru

S. G. M. AMAHEKA, FUAD H. OHORELLA, JESICA NAHUMURY :

Analisis Biaya Operasnal Kendaraan di Kota Ambon

MEIDY KEMPA :

Kajian Tentang Faktor-Faktor yang Mempengaruhi Keterlambatan Proyek Gedung di

Kota Ambon : Peringkat Faktor \& Solusi Penanggulangannya

SAMMYLES G. M. AMAHEKA, ARIVIANA L. KAKERISSA:

Pengaruh Penerapan Keselamatan Dan Kesehatan Kerja Terhadap Biaya Proyek

Konstruksi Bangunan Gedung di Kota Ambon

PIETER TH. BERHITU :

Model Stuktural Aspek Peran Zonasi dan Masyarakat dalam Pengelolaan Pesisir Kota

Ambon Berkelanjutan

\section{Tambahan}

RIKHARD UFIE, ROY R. LEKATOMPESSY, ZICO MARLISSA:

Kaji Kapasitas Pendinginan Ikan dengan Menggunakan Es dalam Kemasan Plastik

FELLA GASPERSZ, ABDUL DJABAR TIANOTAK, RUTH P. SOUMOKIL:

Kajian Kualitas Kelas Awet Limbah Batang Kulit Pohon Sagu Sebagai Material Alternatif Bangunan Kapal

ABDUL DJABAR TIANOTAK, H. C. RIRIMASSE, ELVERY B. JOHANNES:

Uji Kelayakan Ekonomis Pengembangan Fasilitas Bongkar Muat dan Turun Naiknya Penumpang di Pelabuhan Hurnala Maluku Tengah

H. C. RIRIMASSE, ABD. DJABAR TIANOTAK, ELVERY B. JOHANNES :

Penentuan Sistim Trasportasi Unggulan Di Kawasan Pengembangan Ekonomi

Terpadu (Kapet) Seram Provinsi Maluku

BILLY J. CAMERLING :

Pemilihan Alternatif Bahan Bakar Mesin Pembangkit PLTD Menggunakan Metode Value Engineering 
Kelamkak Bidana Kailean:

TEKNIIK MESINN

TEKNIIK INFORMATIIKA

FISIIKA 


\title{
PLTS DI PULAU OSI DAN PERMASALAHANNYA
}

\author{
Antoni Simanjuntak ${ }^{1}$, Johanis Lekalette ${ }^{2}$ \\ e-mail: ${ }^{1)}$ antoni_s15@yahoo.com, ${ }^{2}$ anissdl.69@gmail.com \\ 1) Fakultas Teknik Universitas Pattimura Jl. Ir. M.Putuhena Poka Ambon, Indonesia 97233 \\ 2) Pusat Penelitian Laut Dalam - LIPI, J1. Syaranamual Guru-guru Poka Ambon, Indonesia, 97233
}

\begin{abstract}
Abstrak
Penelitian ini bertujuan untuk mengkaji sistem dan permasalahan PLTS di Pulau Osi kaitannya dengan faktor lingkungan sebagai acuan untuk pembangunan PLTS di pulau-pulau kecil lainnya. Pulau Osi terletak di Kabupaten Seram Bagian Barat dengan luas 7,34 ha, yang dihuni oleh 927 jiwa yang sebagian besar adalah nelayan. Pulau Osi memiliki potensi kekayaan laut yang tinggi, dengan adanya ekosistem mangrove, padang lamun dan terumbu karang yang luas untuk kehidupan biota laut ekonomis. Kelangkaan air bersih masih menjadi masalah utama untuk memenuhi kebutuhan masyarakat dan pariwisata, karena faktor biofisik Pulau Osi yang mempunyai tangkapan air rendah dan sumber daya air tawar tidak tersedia. Pemerintah pada tahun 2012 telah berupaya mengatasi masalah ini dengan membangun sistem pengolahan air bersih teknologi RO (reverse osmosis), menggunakan PLTS (pembangkit listrik tenaga surya) berkapasitas $2,628 \mathrm{KW}$, namun sistem ini hanya efektif selama dua tahun karena belum adanya peran kelembagaan yang bertanggung jawab untuk keberlanjutan sumber daya PLTS tersebut. PLTS Pulau Osi terdiri dari modul PV array, SCC (Solar Charge Controller), baterai, dan inverter ke 220VAC dengan konverter DC-AC sinyal SPWM (sine pulse with modulation) gelombang penuh. Hasil investigasi terdapat keretakan pada sebagian besar baterai karena unit SCC tidak bekerja optimal dalam mengatur pengisian, dan laju korosi yang tinggi terlihat pada bahan logam yang digunakan untuk rak baterai dan pada sebagian besar komponen pengolah air bersih. Faktor yang mempengaruhi adalah; kadar garam dengan salinitas yang tinggi (34,1 ppt) dan suhu udara mencapai $34^{\circ} \mathrm{C}$ menaikan uap air, disebabkan karena konstruksi rumah pembangkit tidak sesuai standar untuk melindungi sistem.
\end{abstract}

Kata kunci : PLTS, Rumah Pembangkit, Korosi, Pulau Kecil.

\section{PENDAHULUAN}

Pulau-pulau kecil di Kawasan Timur Indonesia memiliki potensi sumber daya laut yang besar karena didukung oleh tiga ekosistem utama yaitu terumbu karang, padang lamun (seagrass) dan hutan mangrove. Fungsi ekonomis pulau-pulau kecil dengan sumber daya kelautan dan pusat wisata bahari yang potensial akan dikembangkan sebagai wilayah bisnis yang berbasis sumber daya.

Pulau Osi merupakan salah satu pulau kecil dalam petuanan Negeri Eti di Kabupaten Seram Bagian Barat. Luas Pulau Osi hanya sekitar 7,34 ha, yang dihuni oleh 224 keluarga dengan 927 jiwa (sumber tokoh masyarakat). Pulau Osi terhubung dengan dataran Pulau Seram melalu jembatan kayu yang panjangnya sekitar $1,8 \mathrm{~km}$ untuk sarana transportasi ekonomi dan pendidikan. Permasalahan di Pulau Osi adalah kelangkaan air bersih karena karakteristik lingkungan yang secara biofisik mempunyai tangkapan air sangat rendah dan sumber daya air tawar tidak tersedia.

Upaya pemerintah dalam mengatasi kelangkaan air tawar di Pulau Osi telah dilakukan sejak tahun 2012, dengan pembangkit listrik tenaga surya (PLTS), merupakan program pemanfaatan energi terbarukan di pulau-pulau kecil. Kepulauan Indonesia dengan iklim tropis mempunyai potensi energi surya yang besar, dengan radiasi matahari rata-rata yang tinggi sepanjang tahunnya (Hasan,
2012). Penggunaan energi surya merupakan energi alternatif yang bersih, tidak berpolusi, aman dan persediaannya tidak terbatas yang dikenal dengan energi terbarukan (Akhmad, 2011).

Teknologi (PLTS) fotovoltaik di Pulau Osi menggunakan sistem off grid yang dilengkapi dengan baterai, sehingga dapat bekerja pada siang dan malam hari tanpa terhubung dengan jaringan PLN. Daya yang dihasilkan oleh modul surya adalah 2,628 kW, sedangkan daya yang dihasilkan oleh baterai dapat mencapai $54 \mathrm{~kW}$. Pengolahan air bersih menggunakan teknologi RO (reverse osmosis) dengan sumber air laut pada jarak 600 meter dari posisi PLTS. Menurut tokoh masyarakat Pulau Osi, air bersih yang dihasilkan telah teruji di laboratoium kesehatan dengan kualitas baik dan layak untuk dikomsumsi.

Sistem PLTS dan pengolahan air bersih di Pulau Osi hanya berfungsi selama dua tahun, dan kerusakan disebabkan korosi pada sebagian besar peralatan RO yang mengandung logam. Korosi merupakan serangan yang bersifat merusak pada suatu logam oleh reaksi kimia dengan lingkungannya (Trethweyet al. 1991). Proses korosi pada logam sangat dipengaruhi oleh faktor lingkungan terutama kadar garam (salinitas) dan suhu dikemukakan dalam Fontana (1994). Salinitas adalah jumlah total kandungan garam terlarut dalam $1 \mathrm{~kg}$ air laut yang dinyatakan dalam bagian per 
seribu (\%) (Steward, 2004). Rumah pembangkit mempunyai fungsi melindungi sistem PLTS dari lingkungan luar, cuaca dan akses tanpa izin.

Sehubungan dengan pentingnya PLTS sebagai energi terbarukan yang sangat efektif dikembangkan untuk pulau-pulau kecil, maka dilakukan penelitian untuk mengkaji sistem PLTS di Pulau Osi dan permasalahannya.

\section{TUJUAN}

Penelitian ini bertujuan untuk mengkaji sistem dan permasalahan PLTS Pulau Osi kaitannya dengan faktor lingkungan sebagai acuan untuk pembangunan PLTS di pulau-pulau kecil lainnya.

\section{KAJIAN TEORI}

\section{Potensi Energi Surya di Indonesia}

Energi berperan sangat penting dalam mendorong pertumbuhan ekonomi. Energi listrik dibutuhkan untuk berbagai proses kegiatan meliputi mekanik, panas, dan lain - lain. Memasuki abad 21, persediaan minyak dan gas bumi semakin menipis, sementara kebutuhan akan energi semakin meningkat.

Letak geografis Indonesiadi wilayah tropis atau sekitar khatulistiwa mempunyai waktu pencahayaan matahari terbanyak sepanjang tahun. Kondisi ini menyebabkan Indonesia memiliki potensi energi surya cukup besar yang mencapai $4,8 \mathrm{KWh} \mathrm{m}^{2}$ atau setara dengan 112,999 GWp (AgroIndonesia, 2016). Potensi tenaga surya di Indonesia secara umum berada pada tingkat good (baik) yang dapat dijadikan sebagai salah satu patokan dalam pengembangan Pembangkit Listrik Tenaga Surya (PLTS). Hampir seluruh daerah di Indonesia berpotensi untuk dikembangkan PLTS, dengan distribusi penyinaran daya rata-rata mencapai 4.8 $\mathrm{kWh} / \mathrm{m}^{2}$. Jumlah terbesar pada tingkat radiasi matahari berada di Indonesia Timur yaitu 5,1 $\mathrm{kWh} / \mathrm{m}^{2} /$ hari dengan variasi bulanan $9 \%$, dan di bagian Indonesia Barat $4,5 \mathrm{kWh} / \mathrm{m}^{2} /$ hari dengan variasi bulanan $10 \%$.

\section{Sistem Pembangkit Listrik Tenaga Surya PLTS Off-Grid}

Suatu PLTS off-grid yang dikelola secara komunal atau yang sering disebut sistem PLTS berdiri sendiri(stand-alone), beroperasi secara independen tanpa terhubung dengan jaringan PLN. Sistem ini membutuhkan baterai untuk energi listrik yang dihasilkan di siang hari untuk memenuhi kebutuhan listrik di malam hari. Ada dua konfigurasi sistem PLTS off-grid yang umum digunakan yang akan dijelaskan dalam bab ini, yaitu sistem penyambungan DC atau DC-coupling (Gambar 1) dan penyambungan $\mathrm{AC}$ atau $A C$-coupling (Gambar 2).

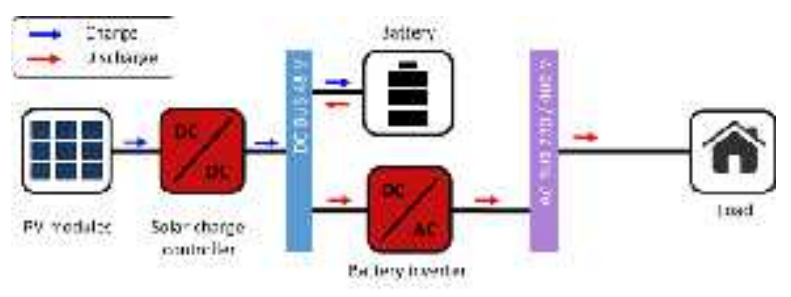

Gambar 1. Konfigurasi Sistem DC coupling Sumber: Dos \& Dont'ts

Sistem dianggap memiliki konfigurasi penyambungan sistem DC (DC-coupling) jika komponen utamanya terhubung di bus DC. Daya listrik dibangkitkan oleh modul fotovoltaik dan digunakan untuk mengisi baterai melalui solar charge controller. SCC adalah pengonversi DC-DC untuk menurunkan tegangan modul fotovoltaik ke level tegangan baterai yang juga dilengkapi dengan maximum power point tracker (MPPT) untuk mengoptimalkan penangkapan energi.

Di siang hari, dengan radiasi sinar matahari yang cukup, baterai diisi untuk mencapai kondisi pengisian (SoC, state of charge) yang maksimal. Seiring dengan meningkatnya permintaan listrik hingga beban melebihi daya larik fotovoltaik yang terhubung, inverter baterai akan menyalurkan energi dari baterai ke beban dan akan berhenti beroperasi ketika SoC baterai mencapai batas minimum.

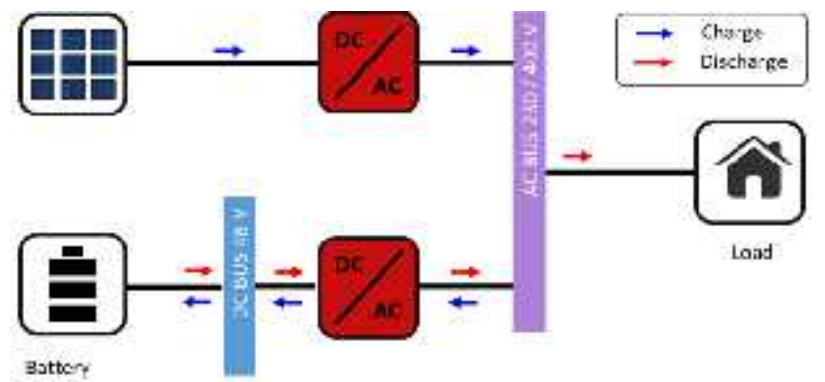

Gambar 2. Konfigurasi Sistem AC coupling

Komponen utama yang membedakan sistem $A C$ coupling dengan DC-coupling adalah inverter jaringan. Dalam konfigurasi $A C$-coupling, modul fotovoltaik dan baterai dihubungkan di bus AC melalui inverter jaringan dan inverter baterai. Modul fotovoltaik terhubung ke inverter jaringan dimana tegangan diubah dari DC ke AC. Serupa dengan charge controller, inverter jaringan juga dilengkapi dengan perangkat MPPT untuk mengoptimalkan penangkapan energi. Daya dari rangkaian modul fotovoltaik dapat langsung digunakan oleh beban di siang hari dan kelebihannya digunakan untuk mengisi baterai melalui inverter baterai pada saat yang sama. 


\section{Modul Fotovoltaik}

Modul fotovoltaik terdiri dari sejumlah sel fotovoltaik yang saling terhubung secara seri dan diproduksi menjadi sebuah unit. Sel-sel tersebut berikut dengan kawat busbar penghubungnya dilindungi oleh bahan pelapis atau enkapsulasi (encapsulating material) yang melindungi sel-sel dari kontak langsung dengan lingkungan dan kekuatan mekanik yang dapat merusak sel-sel yang tipis. Kinerja kelistrikan modul fotovoltaik dicirikan dengan kurva arus-tegangan (I-V). Kurva tersebut menjelaskan operasi arus dan tegangan modul fotovoltaik pada radiasi sinar matahari dan suhu tertentu. Karena modul fotovoltaik merupakan komponen utama dalam PLTS, kualitas modul fotovoltaik yang baik sangatlah penting untuk mempertahankan operasional sistem.

\section{Solar Charge Controller}

Fungsi utama dari solar charge controller (Gambar 3) dalam sistem PV off-grid adalah untuk melindungi baterai dari pengisian berlebih dan pengosongan berlebih, dan untuk memastikan pengisian baterai yang efisien.

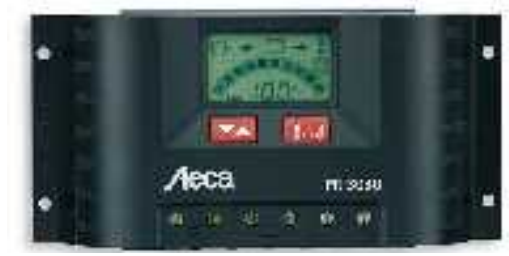

Gambar 3. Solar Charge Controller Steca Sumber: PV System Handout Book - Indonesia

\section{Baterai}

Baterai adalah salah satu komponen dari PLTS yang berfungsi untuk menyimpan energi listrik yang dihasilkan oleh modul fotovoltaik. Baterai pada sistem PLTS dapat dioperasikan secara paralel (Gambar 4) atau secara seri (Gambar 5).

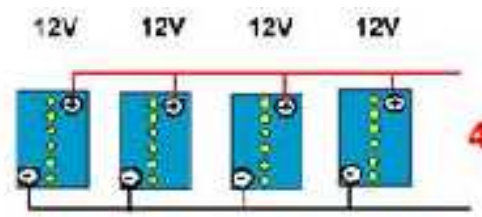

\section{Ah}

100Ah TOEAh TDOAh TDOAh

Gambar 4. Rangkaian Paralel Baterai

$8 \mathrm{~V}$

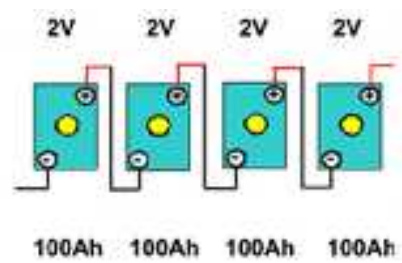

100Ah

Gambar 5. Rangkaian Seri Baterai

\section{Inverter Baterai}

Inverter baterai (Gambar 6) atau juga dikenal sebagai inverter yang berdiri sendiri (stand-alone) adalah otak dari sistem PLTS off-grid berbasis komunal. Inverter baterai bertugas untuk membentuk jaringan distribusi AC dengan mengatur tegangan dan frekuensi dalam batas yang diijinkan dan menjaga keseimbangan energi di dalam jaringan. Inverter baterai biasanya dapat digunakan secara dua arah (bidirectional) atau satu arah (unidirectional) tergantung pada konfigurasi dari sistem. Dalam sistem penyambungan AC-coupling, inverter baterai berfungsi sebagai inverter (pengubah tegangan DC-AC) serta charger (pengubah tegangan AC-DC). Jika terdapat kelebihan energi dari modul fotovoltaik dan baterai tidak terisi penuh, inverter baterai bertindak sebagai charger. Dan jika terdapat kekurangan energi dan baterai masih memiliki energi yang tersisa, baterai akan mengeluarkan daya untuk memenuhi permintaan melalui inverter.

Beberapa inverter baterai dapat ditingkatkan dayanya atau diinterkoneksikan secara modular untuk mencapai keluaran (output) yang lebih besar. Inverter baterai dapat dikonfigurasi secara paralel sebagai klaster tunggal (single-cluster) dalam konfigurasi satu fasa atau tiga fasa serta beberapa klaster (multi-cluster) dengan panel distribusi tambahan. Dalam konfigurasi multi-cluster, jika satu klaster tambahan bermasalah, yang lainnya masih dapat beroperasi.

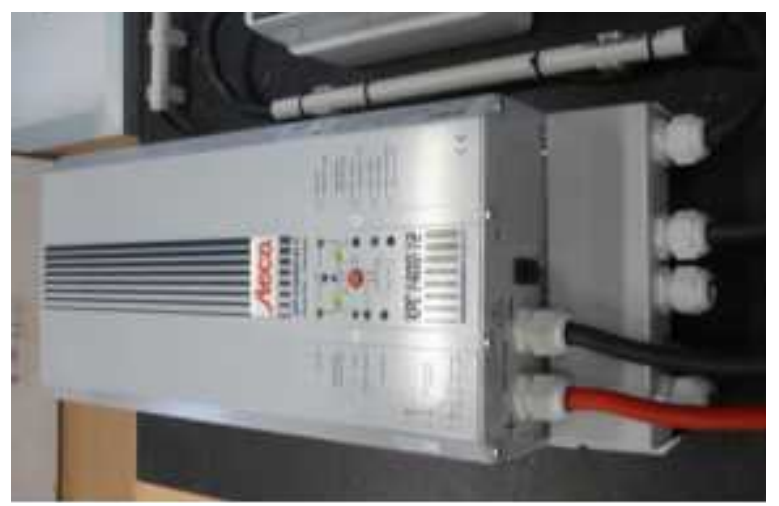

Gambar 6. Inverter Baterai Steca

\section{Rumah Pembangkit}

Rumah pembangkit adalah tempat untuk melindungi seluruh perangkat, terutama peralatan listrik yang sensitif dari lingkungan luar, cuaca, serta akses tanpa izin.

Beberapa hal yang harus dipertimbangkan saat membangun rumah pembangkit yakni:

- Rumah pembangkit harus dirancang dengan ventilasi dan pencahayaan yang cukup, serta aman dari air dan gangguan binatang. Insulasi panas yang baik harus disediakan untuk mengurangi kenaikan temperatur di dalam rumah pembangkit akibat paparan sinar matahari. 
- Lahan harus aman dari resiko bencana alam seperti banjir atau tanah longsor.

Tanda peringatan terhadap risiko bahaya dalam pekerjaan kelistrikan, seperti tersengat listrik serta ledakan, harus tersedia pada sistem pembangkit untuk meningkatkan kesadaran operator dan teknisi.

\section{Karakteristik Pulau-Pulau Kecil}

Indonesia merupakan negara kepulauan dengan jumlah pulau-pulau kecil lebih dari 10.000 buah. Potensi sumber daya alam daratan Pulau-pulau kecil sangat terbatas, namun memiliki potensi sumber daya laut yang cukup besar. Batasan pulau kecil mempunyai luas area kurang dari $2.000 \mathrm{~km}^{2}$ (UU No. 27 Tahun 2007). Pulau kecil mempunyai karakteristik biofisik yang menonjol, yaitu: (1) tangkapan air yang terbatas dan sumber daya/cadangan air tawar yang sangat rendah dan terbatas; (2) peka dan rentan terhadap berbagai tekanan (stressor) dan pengaruh eksternal baik alami maupun akibat kegiatan manusia, seperti badai dan gelombang besar serta pencemaran, (3) mempunyai sejumlah besar jenis-jenis (organisme) endemik dan keanekaragaman yang tipikal dan bernilai tinggi (Bengen, 2000; Ongkosongo, 1998; Sugandhy, 1998).

Suhu permukaan laut Nusantara berkisar antara $28-38^{\circ} \mathrm{C}$, dipengaruhi oleh radiasi matahari, kondisi awan, serta proses interaksi antar air dan udara seperti alih bahang, penguapan dan hembusan angin. Suhu di perairan pantai biasanya lebih tinggi dari laut lepas (Nontji, 1993). Suhu permukaan laut lepas berkisar antara $26,0-31,5^{\circ} \mathrm{C}$ (Syaifullah, 2018). Salinitas atau jumlah kandungan garam terlarut dalam $1 \mathrm{Kg}$ air laut, berada pada kisaran 0 $40 \%$ atau $0-40 \mathrm{~g} / \mathrm{Kg}$ air laut. Salinitas permukaan laut Nusantara secara umum berkisar antara $32-34$
PSU (Dahuri, 1996). Salinitas dipengaruhi oleh muara sungai, curah hujan, evaporasi, musim, serta interaksi laut dengan daratan.

Pasang surut atau pasut yang terjadi secara hampir periodik merupakan fenomena alam yang sering terlihat di perairan pantai. Naik turunnya muka laut dapat terjadi sekali sehari (pasut tunggal), atau dua kali sehari (pasut ganda), dan pasut yang berperilaku di antara keduanya disebut pasut campuran (Dahuri, 1996). Tipe pasang surut di perairan timur Indonesia adalah pasut harian ganda campuran (Mossa et al, 1995). Untuk memprediksi kondisi pasut dengan akurat diperlukan waktu pengukuran paling sedikiit 15 hari, atau selama 18,6 tahun (Pariwono, 1985). Perhitungan pasang surut yang umum menggunakan metode Admiralty, dimana permukaan air laut rata-rata diperoleh dengan menghitung konstanta-konstanta pasang surut (komponen dinamik pasang surut).

Pengetahuan tentang waktu, tinggi air dan arus pasang surut sangat penting untuk navigasi, kegiatan rekayasa pantai, keperluan militer, penangkapan ikan, dan olahraga bahari.

\section{METODE}

Penelitian ini dilakukan selama dua hari di Pulau Osi Kabupaten Seram Bagian Barat, peta lokasi ditunjukkan pada Gambar 7. Kegiatan penelitian meliputi; inspeksi pada sistem PLTS untuk melayani alat pengolah air bersih, dilanjutkan dengan pengukuran pasang surut selama 24 jam. Inspeksi pada sistem PLTS dimulai pemeriksaan modul surya, solar charge controller, baterai, dan rumah pembangkit. Alat ukur tegangan dan arus menggunakan clamp meter AC dan DC merk DEKO 1000A CM-1000DR, ditunjukkan pada (Gambar 8).

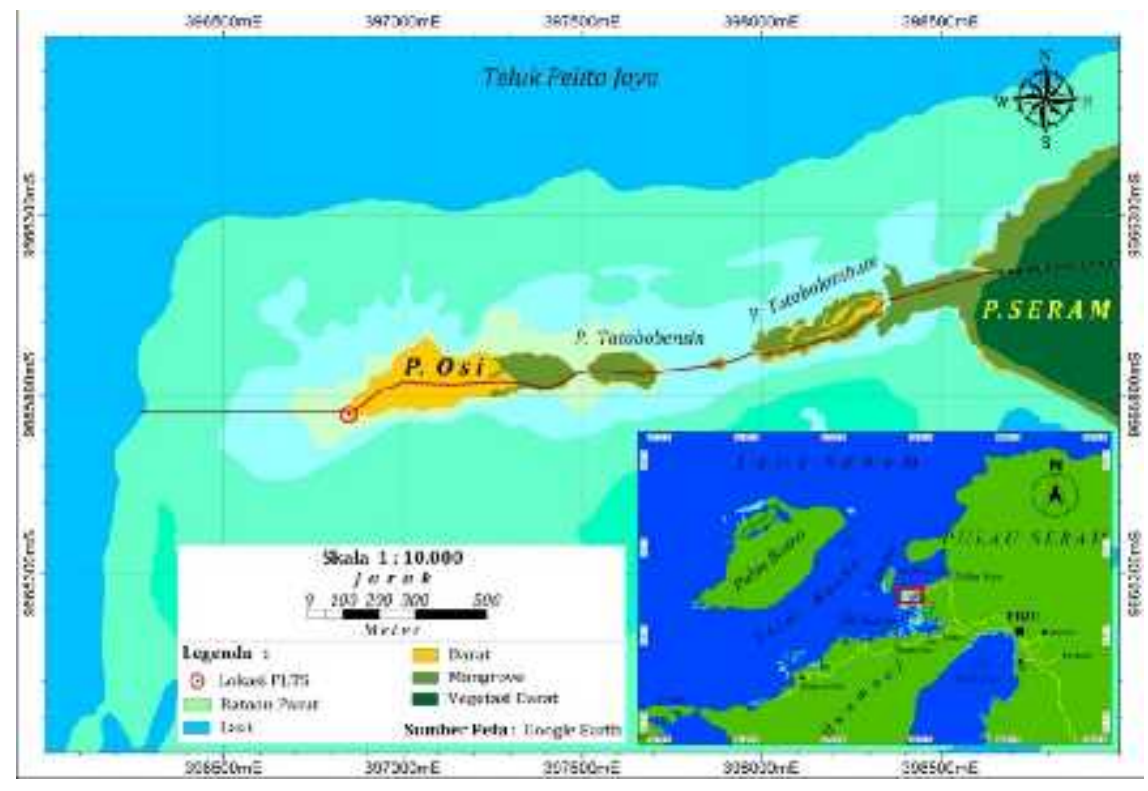

Gambar 7. Peta Lokasi penelitian. 
Studi kelayakan rumah pembangkit mengacu kepada kajian teori. Pengukuran beda elevasi antara tinggi pondasi rumah pembangkit dengan permukaan air tertinggi dilakukan dengan mengamati pasang surut pada pasang tertinggi (spring tide), tanggal $23-24$ Maret 2019.Pengamatan menggunakan mistar pasut (Gambar 9a) di sekitar lokasi penelitian yang masih tergenang air pada surut terendah, pada koordinat posisi $3^{\circ} 1^{\prime} 25,89^{\prime \prime} \mathrm{S}$ dan $128^{\circ} 4^{\prime} 19.06^{\prime \prime}$. Penentuan posisi menggunakan GPS Garmin 78s (Gambar 9b). Pengamatan mistar pasut dengan interval waktu 30 menit, menggunakan alat tulis dan senter. Pasang tertinggi pada mistar pasut ditandai dengan cat, kemudian pengukuran beda elevasi ke tinggi pondasi menggunakan waterpass selang, rambu ukur, dan meter roll.

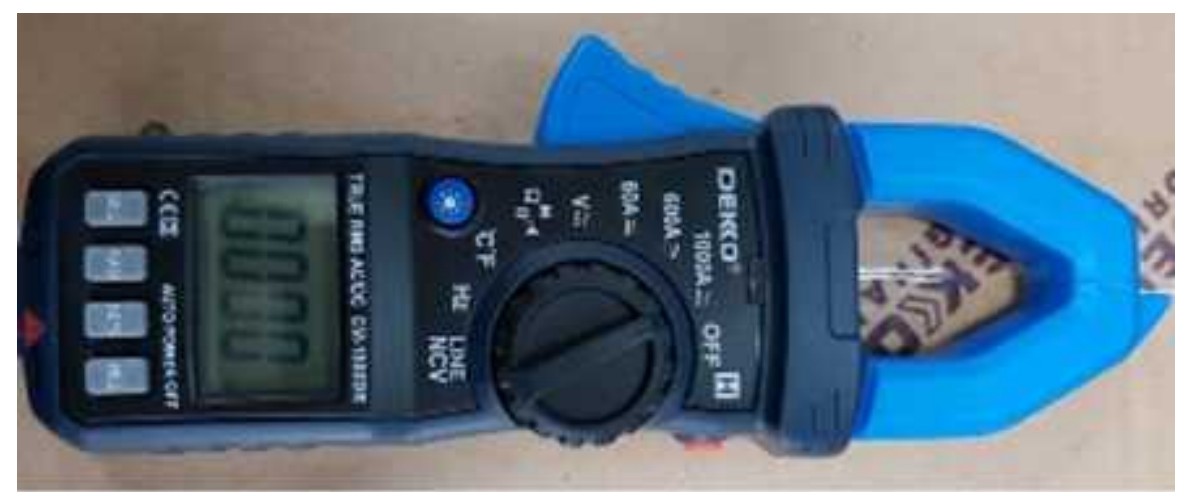

Gambar 8. Clamp meter
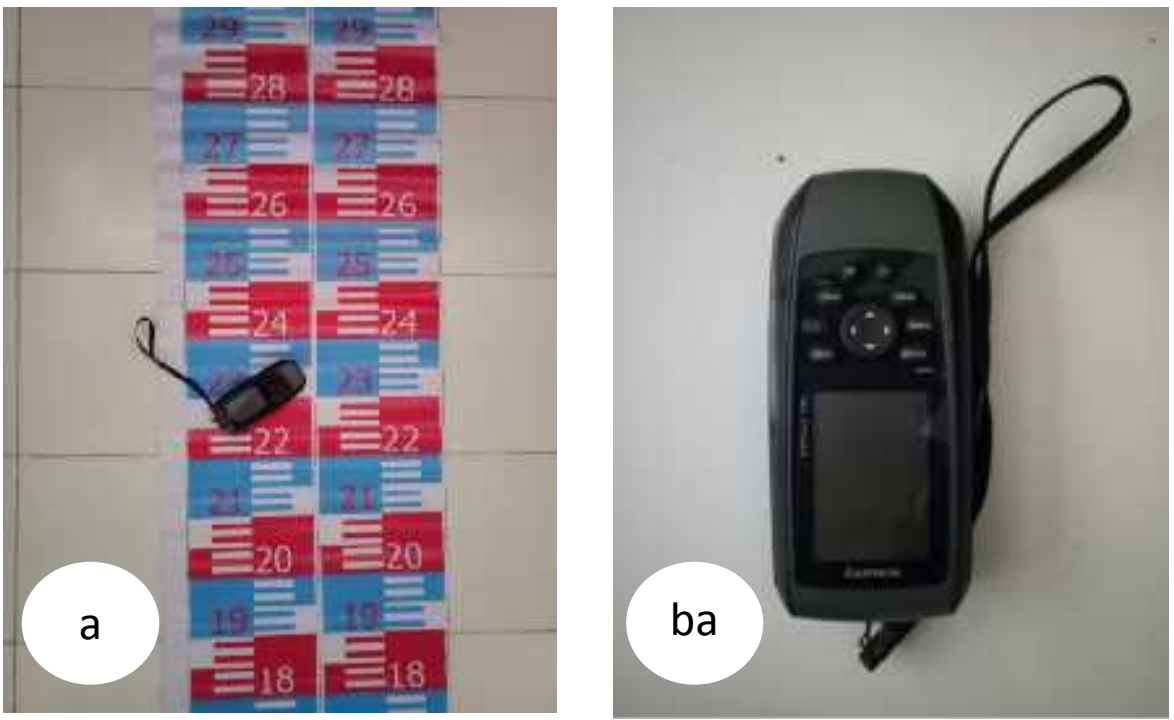

Gambar 9. Mistar pasut (a) dan GPS Garmin 78s (b)

\section{HASIL DAN PEMBAHASAN}

PLTS di Pulau Osi terdiri modul PV array, SCC (Solar Charge Controller), baterai, dan inverter dengan blok diagram sistem ditunjukkan pada Gambar 10. Modul PV array dibagi dua kelompok (Gambar 11a dan 11b), masing-masing 20 modul, dengan konfigurasi paralel 4 string, dimana1string berjumlah 10 modul. Kelompok 1 mempunyai struktur; tinggi pondasi $0,41 \mathrm{~m}$, tinggi PV array dari pondasi $0,67-1,03 \mathrm{~m}$, kemiringan $6,2^{\circ}$ ke arah $67^{\circ}$. Kelompok PV array 2 berada di atap rumah pembangkit, tinggi $2,8-3,0 \mathrm{~m}$, kemiringan $1^{\circ} \mathrm{ke}$ $\operatorname{arah} 250^{\circ}$.

Modul PV yang digunakan mempunyai karakteristik;

$\begin{array}{lll}\text { Jumlah cell/module } & & 60 \text { cell } \\ \text { Kapasitas Daya/modul } & & 260 \mathrm{Wp} \\ \text { Rated Max. Power } & \mathrm{P}_{\mathrm{MAX}} & 260 \mathrm{~W} \\ \text { Open Circuit Voltage } & \mathrm{V}_{\mathrm{OC}} & 38,40 \mathrm{~V} \\ \text { Rated Voltage } & \mathrm{V}_{\mathrm{MPP}} & 31,40 \mathrm{~V} \\ \text { Short Circuit Current } & \mathrm{I}_{\mathrm{SC}} & 8,94 \mathrm{~A} \\ \text { Rated Current } & \mathrm{I}_{\mathrm{MPP}} & 8,37 \mathrm{~A} .\end{array}$

Perhitungan daya keluaran pada PV array berdasarkan karakteristik modul adalah;

1. Satu string (10 modul PV) mempunyai arus $\mathrm{I}_{\mathrm{MPP}}$ $=8,37$ A dan tegangan $\mathrm{V}_{\mathrm{MPP}}=31,4 \mathrm{~V}$,

2. Paralel 4 string (PV array)mempunyai arus $\mathrm{I}_{\mathrm{MPP}}$ $=33,48 \mathrm{~A}$ dan tegangan $\mathrm{V}_{\mathrm{MPP}}=314 \mathrm{~V}$, sehingga daya keluaran PV array adalah, 
Daya $=\mathrm{I}_{\mathrm{MPP}} \times \mathrm{V}_{\mathrm{MPP}}=8,37 \mathrm{~A} \times 314 \mathrm{~V}=2628$ watt atau $2,628 \mathrm{KW}$.

Peralatan SCC (Sollar Charge Controller) seri GSA220 digunakan sebagai unit intelijen PV yang terintegrasi dengan power inverter (Gambar 12a). Unit SCC mempunyai tegangan input PV berkisar 187 - 300VDC, suplai ke inverter 255VDC, tegangan baterai dijaga pada 240VDC, dan pengisian diproteksi pada 270VDC. Unit baterai menggunakan tipe LCPA 12V250AH (Gambar 12b), dengan konvigurasi seri 18 buah untuk menghasilkan kapasitas $54 \mathrm{KWh}$. Suplai daya dari PV atau baterai ke inverter dirubah menjadi 220VAC dengan konverter DC-AC sinyal SPWM (sine pulse with modulation) gelombang penuh. Tegangan keluaran 220VAC dari inverter dihubungkan ke sistem beban atau pengolah air bersih dengan teknologi RO (reverse osmosis).

Investigasi yang dilakukan pada sistem PLTS Pulau Osi ditemukan beberapa masalah yaitu; terdapat keretakan pada sebagian besar baterai karena unit SCC tidak bekerja optimal dalam mengatur pengisian, dan laju korosi yang tinggi terlihat pada bahan logam yang digunakan untuk rak baterai dan pada sebagian besar komponen pengolah ar bersih (Gambar 13a). Faktor yang mempengaruhi adalah; kadar garam dengan salinitas yang tinggi $(34,1 \mathrm{ppt})$ dan suhu udara mencapai $34^{\circ} \mathrm{C}$ menaikan uap air, disebabkan karena konstruksi rumah pembangkit tidak sesuai standar untuk melindungi sistem (Gambar 13b).

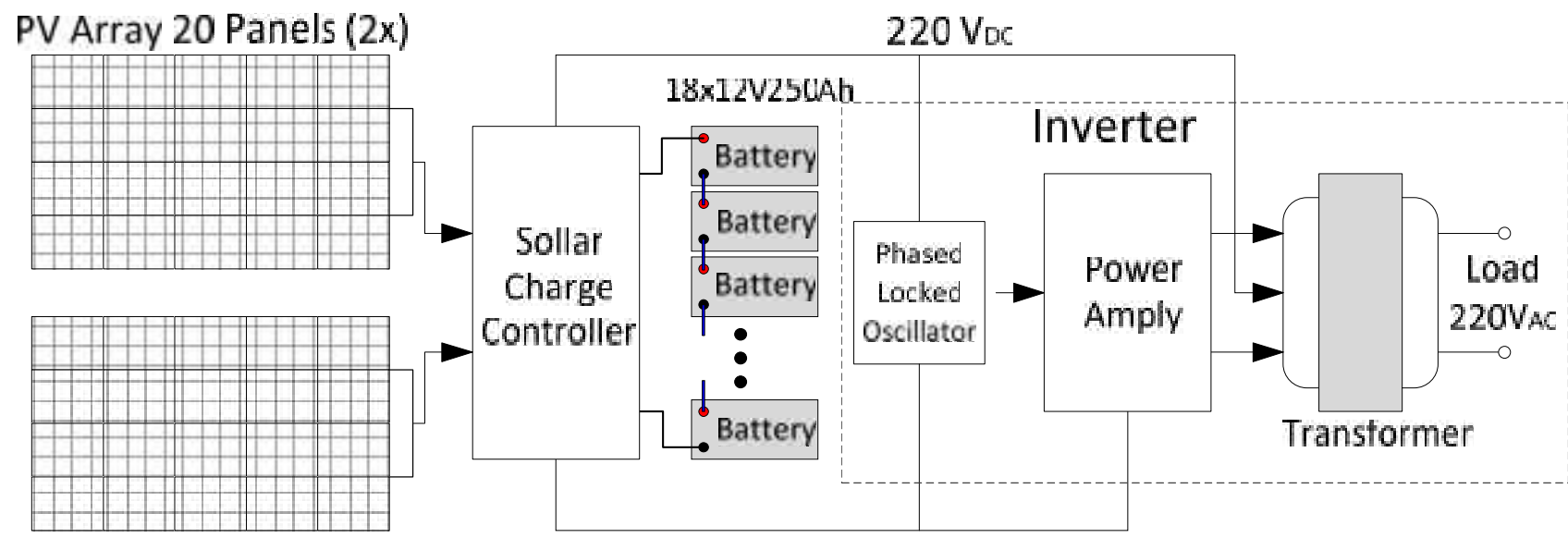

Gambar 10. Blok diagram sistem PLTS di Pulau Osi.
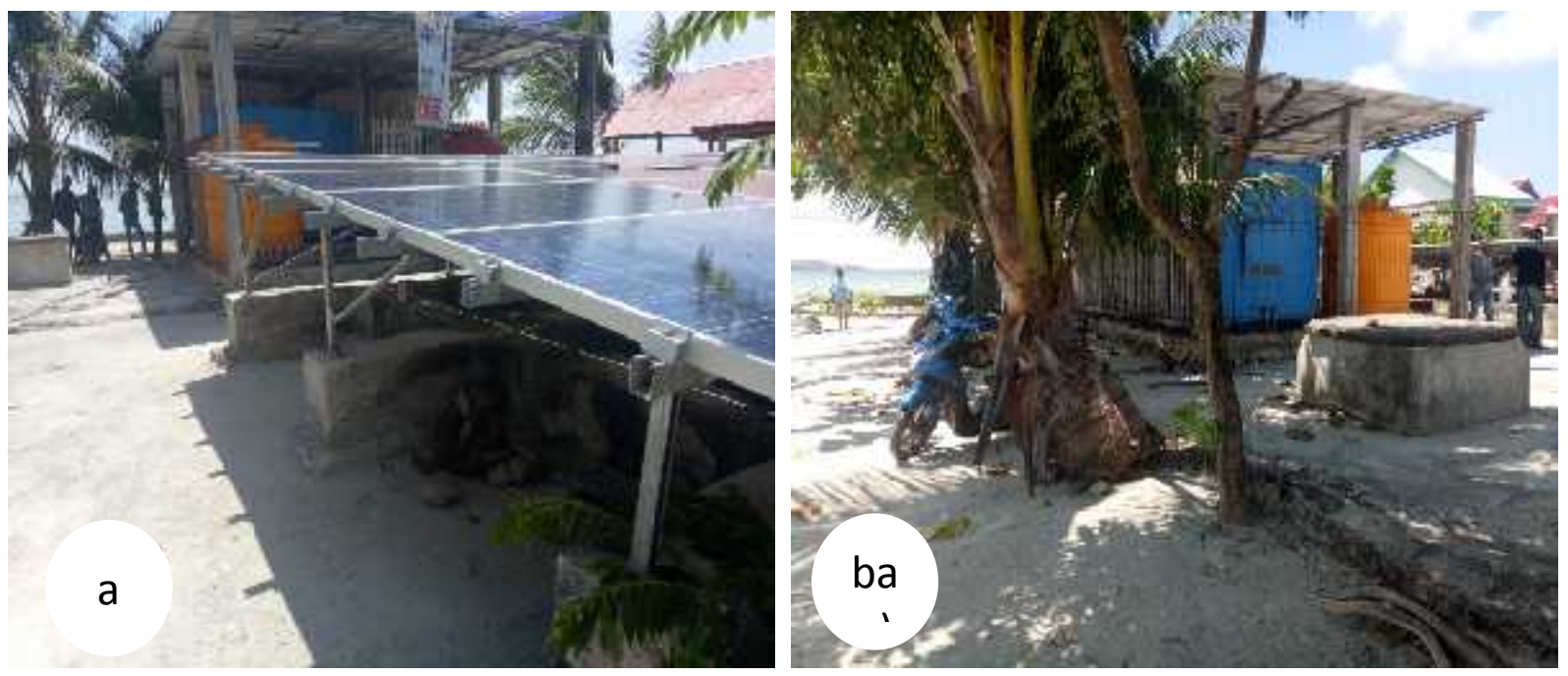

Gambar 11. Letak modul PV array (a), dan rumah pembangkit (b). 

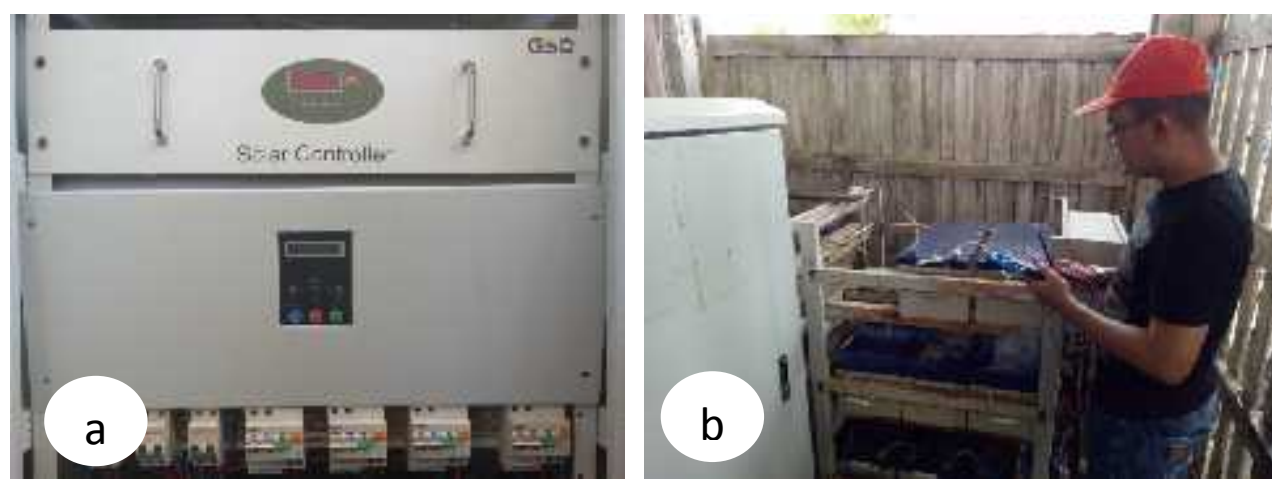

Gambar 12. Peralatan PLTS;(a) unit SCC dan inveter, dan (b) unit baterai.
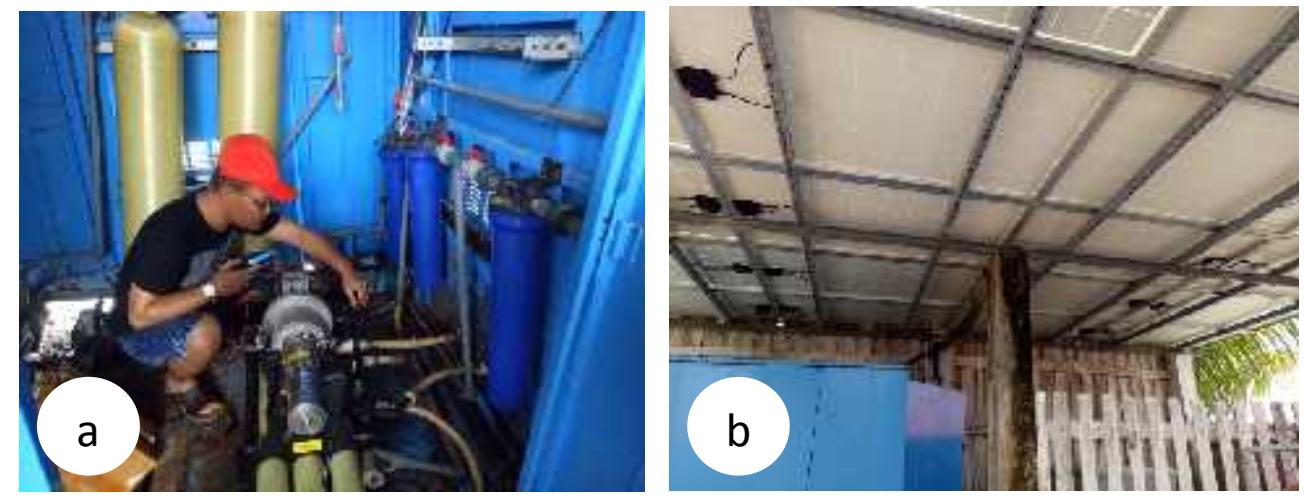

Gambar 13. (a) Korosi pada pada sistem pengolah air bersih,dan (b) kondisi rumah pembangkit.

Tinggi pondasi rumah pembangkit dari muka laut berdasarkan hasil pengamatan pasut pada pasang tertinggi (spring tide) tanggal 23 - 24 Maret 2019 (Gambar 14), mempunyai beda elevasi 0,6 meter, dengan jarak pondasi ke air laut 6,5 meter. Rumah pembangkit (Gambar 13b) yang terlihat tanpa dinding tembok tidak melindungi PLTS dari uap air laut dan sinar matahari. Aktifitas gelombang di Pulau Osi biasanya meningkat pada musim barat (Desember - Februari), dan ombak yang menyusur ke pantai meningkatkan uap air laut. Selain itu, atap rumah pembangkit yang hanya memanfaatkan modul PV tidak memberikan perlindungan pada saat hujan, dan suhu hingga $34^{\circ} \mathrm{C}$ akibat radiasi bahang dari modul PV.

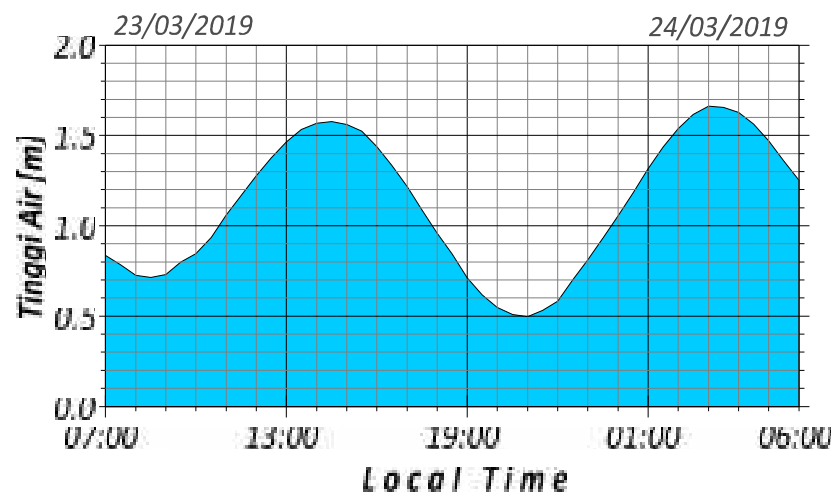

Gambar 14. Pasang surut pada tanggal 23 - 24 Maret 2019

\section{KESIMPULAN}

Kajian sistem dan permasalahan PLTS di Pulau dapat disimpulkan;

- Pembangkit listrik tenaga surya di Pulau Osi telah membantu masyarakat setempat mendapatkan air bersih dengan energy gratis selama dua tahun.

- Rumah pembangkit Pulau Osi tidak melindungi peralatan listrik/elektronik PLTS dari uap air, hujan dan sinar matahari sebagai penyebab kerusakan.

- Penyatuan rumah pembangkit dengan rumah pengolahan air bersih dari sumber air laut bersalinitas $34 \%$ mempercepat proses korosi.

- Pemanfaatan energi baru terbarukan dengan PLTS membutuhkan kelembagaan yang tepat dan kuat, agar pemanfaatan dapat dilakukan secara berkelanjutan.

\section{DAFTAR PUSTAKA}

Akhmad, Kholid, (2011), Pembangkit Listrik Tenaga Surya dan Penerapannya Untuk Daerah Terpencil, Jurnal Dinamika Rekayasa, 1(1): 2833

Bengen, D.G. 2000. Ekosistem dan Sumberdaya Alam Pesisir, Sinopsis. Pusat Kajian Sumberdaya Pesisir dan Lautan, Institut Pertanian Bogor. Fontana, M.G. "Corrosion 
Engineering". New York: McGraw-Hikll Book Company, (1994).

Dahuri, R., J. Rais, P. Ginting dan M.J. Sitepu. 1996. Pengelolaan Sumberdaya Pesisir dan lautan Secara Terpadu. PT. Pradnya Paramita, Jakarta. Hasan, H., (2012), Perancangan Pembangkit Listrik Tenaga Surya Di Pulau Saugi, Jurnal Riset dan Teknologi Kelautan, 10(2): 169-180.

Fontana, M.G. "Corrosion Engineering". New York: McGraw-Hikll Book Company, (1994).

Hasan, H., (2012), Perancangan Pembangkit Listrik Tenaga Surya Di Pulau Saugi, Jurnal Riset dan Teknologi Kelautan, 10(2): 169-180.

http://agroindonesia.co.id/2016/04/indonesia-punyapotensi-besar-kembangkan.

M. D. Jazim Syaifullah, 2018. Suhu permukaan Laut Perairan Indonesia dan Hubungannya dengan Pemanasan Global. Jurnal Segara Vol. 11 No. 1 Agustus 2015:37

Mossa, K.M., I. S. Suwelo, M. Hutomo, R. Dahuri dan S. Salim. 1995. Indonesian Country Study on Integrated Coastal an Marine Biodiversity Management. Ministry of State for Environment Republic of Indonesia in with Cooperation with Directorate for Nature Management Kingdom of Norway.

Nontji. 1993. Laut Nusantara. Buku referensi. Djambatan, Jakarta . 368 hal.
Stewart, R.H. 2004. Introduction to Physical Oceanography. Texas A \& M University, Texas.

Sugandhi, A. 1998. Pengelolaan Lingkungan PulauPulau Kecil dalam Prosiding Seminar dan Lokakarya Pengelolaan Pulau-Pulau Kecil di Indonesia. Kerjasama Departemen Dalam Negeri, Direktorat Pengelolaan Sumberdaya Lahan dan Kawasan - TPSA - BPPT - Coastal Resources Management Project (CRMP) USAID. Trethwey, K.R dan Chamberlain, J. "Korosi untuk Mahasiswa dan Rekayasawan". Jakarta: PT. Gramedia Pustaka, (1991).

Trethwey, K.R dan Chamberlain, J. "Korosi untuk Mahasiswa dan Rekayasawan". Jakarta: PT. Gramedia Pustaka, (1991).

Undang-Undang No. 27 Tahun 2007 Tentang Pengelolaan Wilayah Pesisir dan Pulau-pulau Kecil

Ongkosongo, O.S.R. 1998. Permasalahan Dalam Pengelolaan Pulau-Pulau Kecil dalam Prosiding Seminar dan Lokakarya Pengelolaan PulauPulau Kecil di Indonesia. Kerjasama Departemen Dalam Negeri, Direktorat Pengelolaan Sumberdaya Lahan dan Kawasan TPSA - BPPT - Coastal Resources Management Project (CRMP) USAID. 